\title{
Effects of wheat yield and area under wheat crop on agricultural GDP in Pakistan: An econometric analysis
}

\author{
Abdul Rehman ${ }^{1, *}$, Luan Jingdong ${ }^{1}$, Asif Kabir ${ }^{2}$, Imran Hussain ${ }^{3}$ \\ ${ }^{1}$ College of Economics and Management, Anhui Agricultural University, Hefei, China \\ ${ }^{2}$ School of Communication Engineering, Chongqing University, Chongqing, China \\ ${ }^{3}$ Allama Iqbal Open University, Islamabad, Pakistan
}

\section{A R T I C LE IN F O}

\section{Article history:}

Received 25 March 2017

Received in revised form

2 May 2017

Accepted 18 May 2017

Keywords:

Wheat yield

Agricultural GDP

Crop production

OLS method

Irrigation

\begin{abstract}
A B S T R A C T
This study investigates and explores the relationship between wheat crop yield, area under wheat crop, and agricultural gross domestic product (GDP) in Pakistan. Times series data from 1970-2015 were used in this study. The Phillips-Perron unit root test was used to check the stationarity of the data. The Johansen cointegration test was performed to evaluate the long-term relationships between the dependent and independent variables. An econometric ordinary least square method was applied to estimate the relationship between wheat crop yield, area under wheat crop, and agricultural GDP. The results of the Johansen cointegration test revealed a long-term relationship between the variables. The regression results indicate that wheat crop yield has a positive and significant relationship with agricultural GDP, while the area under wheat crop has a negative relationship with agricultural GDP.
\end{abstract}

(C) 2017 The Authors. Published by IASE. This is an open access article under the CC BY-NC-ND license (http://creativecommons.org/licenses/by-nc-nd/4.0/).

\section{Introduction}

Wheat is an important cereal crop for many countries where it is consumed as a staple food. Two aspects of crop production that have gained increasing importance are sustainability and reliability. For wheat production, water and energy supply are significant requirements and will continue to be essential in the future in order to ensure the sustainability and reliability of production. However, water and energy conservation are two key issues for researchers who have sought to decrease the use and the cost of these two commodities in such a way that production would not be hampered. In the 1980s, Pakistan experienced a golden era of water management: a canal irrigation system was constructed during this time. However, the effects of subsequent drought have stressed irrigation systems. The country experienced difficulty in recovering from the shock following a period of water scarcity that lasted nearly three years from 1999 to 2002. This scarcity in water caused the over-use of ground water though the pumping of ground water and use of wells, which

\footnotetext{
* Corresponding Author

Email Address: abdulrehman@ahau.edu.cn (A. Rehman) https://doi.org/10.21833/ijaas.2017.06.019

2313-626X/C 2017 The Authors. Published by IASE.

This is an open access article under the CC BY-NC-ND license

(http://creativecommons.org/licenses/by-nc-nd/4.0/)
}

consumed a huge amount of available energy despite the country experiencing problems in the provision of this commodity as well (GOP, 2008).

Furthermore, the availability of water for agriculture is expected to decrease from $72 \%$ to $62 \%$ from 1995 to 2020. Globally, this availability has been estimated to decrease from $87 \%$ to $73 \%$ in developing countries (Khan et al., 2006). Pakistan is largely an agricultural country, and water scarcity will thus have disadvantageous impacts on its economy. In addition, Pakistan directly subsidizes several agriculturally related activities, and more than $40 \%$ of labor is directly or indirectly engaged with the agricultural sector (GOP, 2008). In Pakistan, traditional crops, such as wheat, are planted in a flat basin and flooded with water for irrigation. However, huge water losses occur with this type of irrigation. Losses due to evaporation and deep percolation exacerbate severe water shortages, thereby encouraging further groundwater overexploitation. Alternative methods and technologies for crop irrigation are necessary to explore, such as raised bed (RB) technology, for example.

Agriculturists are facing an enormous challenge in order to meet the food requirements of nine billion people by the middle of the 21st century (FAO, 2009). Producing more food from less water in arid and semi-arid areas is one particular challenge for today's agriculture (Shideed, 2011). Water 
shortage and scarcity result in the degradation of land under rainfed agriculture and also lower food production, particularly in the agricultural and semiagricultural zones of Africa (De Fraiture et al., 2010). About $80 \%$ of the world's agriculture comprises of rainfed land, which produces $80 \%$ of global food (Falkenmark et al., 2001; Valipour, 2013; Rehman et al., 2015).

In North Africa and West Asia, 95\% agricultural land is rainfed, while in Uzbekistan, about $40 \%$ of agricultural land is rainfed and has been adversely affected by water shortages (Shaumarov and Birner, 2013; Zakaria et al., 2013). In particular, wheat is an important crop in Pakistan due to its wide consumption (Hussain et al., 2006). In Pakistan, 6.35 million hectares of land are irrigated with channel water and 12.53 million hectares are cultivated using water from wells and for the remaining 3.59 million hectares, no water is available (GOP, 2012). Limited water causes a reduction in wheat biomass, thereby reducing the overall yield of wheat crops (Oweis and Hachum, 2006; Tavakkoli and Oweis, 2004; Xie et al., 2005). The poor and sparsely distributed rainfall in arid regions of Pakistan further aggravates the situation. Small to complete crop losses have occurred under conditions of severe water stress and have been well documented for wheat crops (Oweis, 1997; Rehman et al., 2016a). To combat this issue, the harvesting and utilization of rain water have been successfully applied in many arid regions, wherein runoff water from catchment areas is collected and then direction to crop acreage (Qiang et al., 2006; Short and Lantzke, 2006). Rain water efficiency can be improved with appropriate water harvesting techniques, such as those with a focus on micro-watershed management (Concepcion et al., 2006; Zakaria et al., 2012). Such techniques can increase the capacity of water per unit crop area and also increase productivity (Oweis and Hachum, 2003; Ramotra and Giakwad, 2012; Rehman et al., 2016b).

The effects of irrigation on crop production are usually quantified through the use of crop water production functions, which have examined crop yields under a large variation and number of water applications (English and Raja, 1996).

In many cases, moderate irrigation can significantly increase production yield (Huang et al., 2002). However, as stated by Jin et al. (1999), extreme irrigation results in reduced efficiency in water use by crops, whereas effective water use efficiency leads to higher yields. Similarly, Olesen et al. (2000) showed that the impacts of irrigation on wheat crops are almost entirely due to increased transpiration, while water use efficiency and the harvest index remain unaffected.

Significant differences have been found between soil water content and irrigation rate under different irrigation conditions, crop yield and water use efficiency were found to significantly vary under distinct conditions (Kang et al., 2002). In particular, the effects of limited irrigation and soil water stress on crop yield and water use efficiency can be dependent on the particular growth stage of a crop (Singh et al., 1991).

\section{Production and area used for wheat crop}

Area under wheat crop in hectares and wheat crop yield in $\mathrm{kg} /$ hectares in Pakistan are presented in Fig. 1 and Fig. 2, respectively.

\section{Materials and methods}

Data were collected from a secondary source known as the Pakistan Statistical Year Book (various issues) for the 1970-2015 periods. Three variables were included in the model: wheat crop yield, area under wheat crop, and agricultural gross domestic product (GDP) of Pakistan. To check the stationarity of each variable, a Phillips and Perron (1988) unit root test was applied, including the trend and the intercept, which is appropriate for a finite sample (FAO, 2001). After checking the stationarity of the series, a Johansen cointegration test (Johansen and Juselius, 1990) was applied to examine the long-term relationships between the dependent and independent variables. To this end, the trace statistic and the Max-Eigen statistic were used.

To show the relationship between wheat crop yield, area under wheat crop, and agricultural GDP, an econometric OLS method was applied, and the following model was estimated (Eq. 1):

$Y=A X_{1}^{\beta 1} X_{2}^{\beta 2}$

Taking the natural logarithm of Eq. 1 and considering two explanatory variables, Eq. 1 was converted to the following form (Eq. 2):

$\operatorname{LnY}=\beta_{0}+\beta_{1} \operatorname{Ln} X_{1}+\beta_{2} \operatorname{Ln} X_{2}+\mu$

where

$\beta_{0}=$ Natural logarithm of $A$ (intercept)

$\operatorname{lnY}=$ Natural logarithm of the agricultural GDP per year (in millions of rupees)

$\ln \mathrm{X}_{1}=$ Natural logarithm of wheat yield (in thousand tons)

$\ln \mathrm{X}_{2}=$ Natural logarithm of area under wheat crop (in thousand hectares)

$\mu=$ error term

So, Eq. 2 can also be written as follows (Eq. 3):

$\ln$ (agricultural GDP) $=\beta_{0}+$

$\beta_{1} \ln$ (wheat crop yield) $+\beta_{2} \ln$ (wheat crop area) $+\mu$

\section{Results and discussion}

\subsection{Phillips-Perron unit root test}

The results of the Phillips-Perron unit root test are presented in Table 1 . The stationary of the data was reviewed, including the data trend and the intercept. According to Table 1, agricultural GDP and area under wheat crop are non-stationary, while wheat crop yield is stationary. To transform 
agricultural GDP and area under wheat crop to stationary data, we took their first difference and then once again evaluated their stationarity to confirm the results.

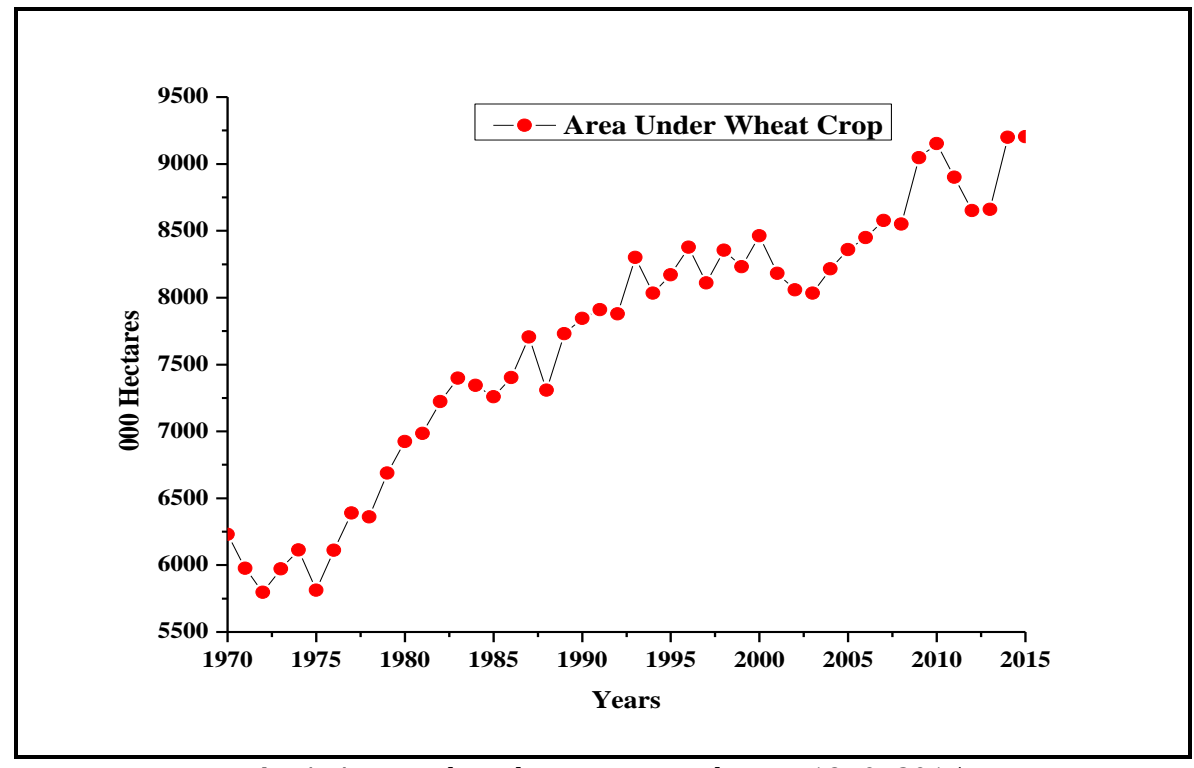

Fig. 1: Area under wheat crop in Pakistan, 1970-2015

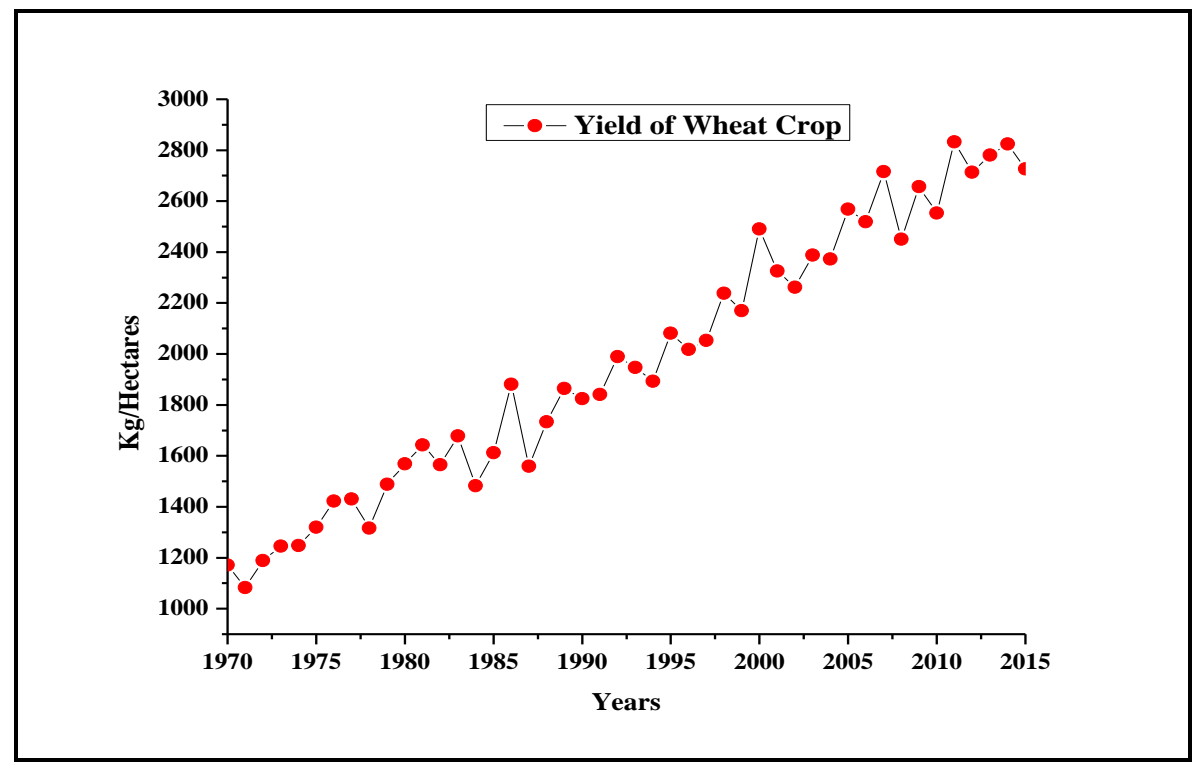

Fig. 2: Yield of wheat crop in kg/hectares in Pakistan, 1970-2015

Table 1: Phillips-Perron unit root test including the trend and the intercept

\begin{tabular}{|c|c|c|c|c|}
\hline \multirow{2}{*}{ Variables } & \multicolumn{2}{|c|}{ At level } & \multicolumn{2}{|c|}{ First Difference } \\
\hline & Adjusted t-statistic & Critical values & Adjusted t-statistic & Critical values \\
\hline Agricultural GDP & $\begin{array}{c}-2.098322 \\
(0.5327)\end{array}$ & $\begin{array}{c}1 \%-4.175640 \\
5 \%-3.513075 \\
10 \%-3.186854\end{array}$ & $\begin{array}{c}-7.036702 * \\
(0.0000)\end{array}$ & $\begin{array}{c}1 \%-4.180911 \\
5 \%-3.515523 \\
10 \%-3.188259\end{array}$ \\
\hline Wheat crop yield & $\begin{array}{c}-4.039289 * \\
(0.0142)\end{array}$ & $\begin{array}{c}1 \%-4.175640 \\
5 \%-3.513075 \\
10 \%-3.186854\end{array}$ & $\begin{array}{c}-19.25221^{*} \\
(0.0000)\end{array}$ & $\begin{array}{c}1 \%-4.180911 \\
5 \%-3.515523 \\
10 \%-3.188259\end{array}$ \\
\hline Wheat crop area & $\begin{array}{c}-2.241455 \\
(0.4560)\end{array}$ & $\begin{array}{c}1 \%-4.175640 \\
5 \%-3.513075 \\
10 \%-3.186854\end{array}$ & $\begin{array}{c}-8.338973^{*} \\
(0.0000)\end{array}$ & $\begin{array}{c}1 \%-4.180911 \\
5 \%-3.515523 \\
10 \%-3.188259\end{array}$ \\
\hline
\end{tabular}

Moreover, the regression results may be spurious due to the lack of cointegration between the study variables. For this purpose, a cointegration technique including the trace statistic and the MaxEigen statistic was used to estimate the long-term relationships between the variables of wheat crop yield, area under wheat crop, and agricultural GDP of Pakistan for the period of 1970-2015. The results of this cointegration analysis are presented in Tables 2 and 3 and reveal the existence of long-term relationships among the variables. The null hypothesis that cointegration does not exist may be rejected. Because the values of the trace statistic and the Max-Eigen statistic are larger than their relevant critical values, one cointegrating equation was able to determine at a $5 \%$ probability level. 
Table 2: Johansen cointegration test using the trace statistic

\begin{tabular}{ccccc}
\hline Eigenvalue & Trace Statistic & $5 \%$ Critical Value & Prob.** & Hypothesized No. of CE(s) \\
\hline 0.422556 & 34.67865 & 29.79707 & 0.0127 & None ${ }^{*}$ \\
0.230473 & 12.16377 & 15.49471 & 0.1492 & At most 1 \\
0.034103 & 1.422613 & 3.841466 & 0.2330 & At most 2 \\
\hline \multicolumn{4}{l}{ Trace test shows 1 co-integrating equation at the 0.05 level; $^{*}$ denotes rejection of the hypothesis at the 0.05 level; ${ }^{* *}$ denotes that values are accurate }
\end{tabular}

Table 3: Johansen cointegration test using the Max-Eigen statistic

\begin{tabular}{ccccc}
\hline Eigenvalue & Max-Eigen Statistic & 5\% Critical Value & Prob.** & Hypothesized No. of CE(s) \\
\hline 0.422556 & 22.51488 & 21.13162 & 0.0318 & None ${ }^{*}$ \\
0.230473 & 10.74116 & 14.26460 & 0.1677 & At most 1 \\
0.034103 & 1.422613 & 3.841466 & 0.2330 & At most 2 \\
\hline \multicolumn{7}{l}{ The Max-Eigen test shows one co-integrating equation at the 0.05 level; ${ }^{*}$ denotes rejection of the hypothesis at the 0.05 level }
\end{tabular}

\subsection{Results of regression analysis}

To show the relationship between wheat crop yield, area under wheat crop, and agricultural GDP in Pakistan over the period of 1970-2015, an econometric ordinary least square (OLS) method was applied.

The regression results are presented in Table 4 . The results showed that the coefficient of wheat crop yield is highly significant at both $1 \%$ and $5 \%$ significance levels, indicating a positive and significant relationship between agricultural GDP and wheat crop yield.

For a $1 \%$ increase in wheat crop yield, agricultural GDP increases by 7.01\%. The results of this study contradict the results of Anyanwu (2010), who used the correlation method and found a negative relationship between wheat crop yield and agricultural GDP in Nigeria. Moreover, the results showed a negative relationship between area under wheat crop and agricultural GDP.

Presently, in Pakistan, wheat production is very low in comparison to developed countries as a result of water shortage and low water availability.

The value of $\mathrm{R}^{2}$ is high (0.84), demonstrating that about $0.84 \%$ of total variation in agricultural GDP is explained by the two considered explanatory variables (wheat crop yield and area under wheat crop). The calculated value for the F-statistic was 114.1596, with a probability value of 0.000000 , suggesting that the overall fitness of model is good.

Table 4: Regression analysis

\begin{tabular}{ccccc}
\hline Variable & Coefficient & Std. Error & t-Statistic & Prob. \\
\hline C & 56.51845 & 16.70161 & 3.384013 & 0.0015 \\
Ln (wheat crop yield) & 7.017328 & 0.938460 & 7.477491 & 0.0000 \\
Ln (wheat crop area) & -12.46102 & 2.836394 & -4.393263 & 0.0001 \\
R-squared: 0.841515; Adjusted R-squared: 0.834144 \\
F-statistic: 114.1596; Prob(F-statistic): 0.000000 \\
Durbin-Watson statistic: 0.863118 \\
\hline
\end{tabular}

\section{Conclusion and recommendations}

This empirical study examined the relationship between wheat crop yield, area under wheat crop, and agricultural GDP in Pakistan for the 1970-2015 periods. Time series data were collected from the Pakistan Statistical Year Book (various issues). To check the stationarity of the data series, PhillipsPerron (PP) unit root tests were applied. The Johansen cointegration test was used to examine the long-term relationships between the dependent and independent variables. An econometric ordinary least square (OLS) method was applied to investigate the relationship among wheat crop yield, area under wheat crop, and agricultural GDP. The results of the Johansen cointegration test revealed a long-term relationship exists among these variables in Pakistan. The results of the regression analysis showed that the coefficient of wheat crop yield was highly significant at both the $1 \%$ and $5 \%$ significance levels with respect to agricultural GDP, indicating a strongly positive and significant relationship between these variables. A $1 \%$ increase in wheat crop yield therefore led to an increase of $7.01 \%$ in agricultural GDP. Finally, the results indicated the presence of a negative relationship between area under wheat crop and agricultural GDP.

\section{Acknowledgement}

The authors are grateful to the School of Economics and Management, Anhui Agricultural University Hefei, China for its financial and moral support. Moreover, the authors are also indebted to the reviewers for their positive suggestion that helped to improve the content of this study.

\section{References}

Anyanwu JC (2010). Poverty in Nigeria: A gendered analysis. The African Statistical Journal, 11: 38-61.

Concepcion RN, Contreras SM, Sanidad WB, Gesite AB, Nilo GP, Salandanan KA, and de Vera SV (2006). Enhancing multifunctionality of agriculture through rainwater harvesting system. Paddy and Water Environment, 4(4): 235-243.

De Fraiture C, Molden D, and Wichelns D (2010). Investing in water for food, ecosystems, and livelihoods: An overview of the comprehensive assessment of water management in agriculture. Agricultural Water Management, 97(4): 495-501.

English M and Raja SN (1996). Perspectives on deficit irrigation. Agricultural Water Management, 32(1): 1-14.

Falkenmark M, Fox P, Persson G, and Rockstorm J (2001). Water harvesting for upgrading of rainfed agriculture: Problems analysis and research needs. SIWI Report II, Stockholm International Water Institute, Stockholm, Sweden. Available 
online at: http://dlc.dlib.indiana.edu/dlc/handle/10535/ 5297

FAO (2001). Speciality Rices of the World: Breeding, production and marketing. Food and Agriculture Organization, ROME, Italy.

FAO (2009). World summit on food security. Food and Agriculture Organization, ROME, Italy.

GOP (2008). Economic survey of Pakistan. Economic Advisory Wing Finance Division, Government of Pakistan, Islamabad, Pakistan. Available online at: http://www.finance.gov.pk/ survey_1009.html

GOP (2012). Pakistan Economic Survey 2010-11. Economic Advisory Wing Finance Division, Government of Pakistan, Islamabad, Pakistan. Available online at: http://www.finance.gov.pk/survey_1011.html

Huang Q, Rozelle SD, Huang J, Wang J (2002). Irrigation and yields in China's agriculture. University of California, Davis, USA.

Hussain I, Khan MA, and Khan EA (2006). Bread wheat varieties as influenced by different nitrogen levels. Journal of Zhejiang University Science B, 7(1): 70-78.

Jin M, Zhang R, Sun L, and Gao Y (1999). Temporal and spatial soil water management: A case study in the Heilonggang region, PR China. Agricultural Water Management, 42(2): 173-187.

Johansen S and Juselius K (1990). Maximum likelihood estimation and inference on cointegration-with applications to the demand for money. Oxford Bulletin of Economics and Statistics, 52(2): 169-210.

Kang S, Zhang L, Liang Y, Hu X, Cai H, and Gu B (2002). Effects of limited irrigation on yield and water use efficiency of winter wheat in the Loess Plateau of China. Agricultural Water Management, 55(3): 203-216.

Khan S, Tariq R, Yuanlai C, and Blackwell J (2006). Can irrigation be sustainable?. Agricultural Water Management, 80(1): 87 99.

Olesen JE, Mortensen JV, Jørgensen LN, and Andersen MN (2000). Irrigation strategy, nitrogen application and fungicide control in winter wheat on a sandy soil. I. Yield, yield components and nitrogen uptake. The Journal of Agricultural Science, 134(01): $1-11$.

Oweis T (1997). Supplemental irrigation: A highly efficient wateruse practice. International Center for Agricultural Research in the Dry Areas (ICARDA), Aleppo, Syria.

Oweis T and Hachum A (2003). Improving water productivity in the dry areas of West Asia and North Africa. In: Kijne JW, Barker R, and Molden DJ (Eds.), Water Productivity in Agriculture: Limits and Opportunities for Improvement: 179 197. CABI Publishing, Wallingford, Oxfordshire, UK.

Oweis $\mathrm{T}$ and Hachum A (2006). Water harvesting and supplemental irrigation for improved water productivity of dry farming systems in West Asia and North Africa. Agricultural Water Management, 80(1): 57-73.

Phillips PC and Perron P (1988). Testing for a unit root in time series regression. Biometrika, 75: 335-346.

Qiang Z, Yuanhong L, and Manjin C (2006). Effect of low rate irrigation with rainwater harvesting system on the dry farming. In the $2^{\text {nd }}$ International RWHM Workshop, Beijing, China.

Ramotra KC and Giakwad VP (2012). Surface rain harvesting potentiality and impact of Dhaval micro-watershed in Satara district, Maharashtra, India. Journal of Environmental Earth Sciences, 2(11): 28-38.

Rehman A, Chandio AA, Jingdong L, and Hussain I (2016b). Economic perspectives of maize crop in Pakistan: A time series analysis (1970-2015) (Part 3). International Journal of Advanced Biotechnology and Research, 7(3): 968-974.

Rehman A, Chandio AA, Jingdong L, Hussain I, Wagan SA, and Memon QUA (2016a). Economic perspectives of cotton crop in Pakistan: A time series analysis (1970-2015) (Part1). Journal of the Saudi Society of Agricultural Sciences. https://doi.org/10.1016/j.jssas.2016.12.005

Rehman A, Jingdong L, Shahzad B, Chandio AA, Hussain I, Nabi G, and Iqbal MS (2015). Economic perspectives of major field crops of Pakistan: An empirical study. Pacific Science Review B: Humanities and Social Sciences, 1(3): 145-158.

Shaumarov M and Birner R (2013). Dryland pastoral systems in transition: What are the options for institutional change in Uzbekistan?. In the 53 ${ }^{\text {rd }}$ Annual Conference of the German Society of Economic and Social Sciences in Agriculture (GEWISOLA), Berlin, Germany: 25-27. Available online at: https://ideas.repec.org/p/ags/gewi13/156133.html

Shideed KH (2011). Informing policy development for sustainable and productive food production systems in dry areas. In the $5^{\text {th }}$ Congress on Conservation Agriculture and $3^{\text {rd }}$ Farming System Design Conference. International Center for Agricultural Research in the Dry Areas, Aleppo, Syria. Available online at: http://aciar.gov.au/files/node/13987/ keynote_theme_3_shideed_88427.pdf

Short R and Lantzke N (2006). Increasing runoff from roaded catchments by chemical application. Department of Agriculture and Food, Western Australia, Australia: 20-24. http://research.wineaustralia.com/wpcontent/uploads/2012/09/RT-03-20-4.pdf

Singh PK, Mishra AK, and Imtiyaz M (1991). Moisture stress and the water use efficiency of mustard. Agricultural Water Management, 20(3): 245-253.

Tavakkoli AR and Oweis TY (2004). The role of supplemental irrigation and nitrogen in producing bread wheat in the highlands of Iran. Agricultural Water Management, 65(3): 225-236.

Valipour M (2013). Increasing irrigation efficiency by management strategies: cutback and surge irrigation. ARPN Journal of Agricultural and Biological Science, 8(1): 35-43.

Xie ZK, Wang YJ, and Li FM (2005). Effect of plastic mulching on soil water use and spring wheat yield in arid region of northwest China. Agricultural Water Management, 75(1): 7183.

Zakaria S, Al-Ansari N, and Knutsson S (2013). Wheat yield scenarios for rainwater harvesting at Northern Sinjar Mountain, Iraq. Natural Science, 5(10): 1057-1068.

Zakaria S, AL-Ansari NA, Knutsson S, and EZZ-Al-deen M (2012). Rain water harvesting at Eastern Sinjar Mountain. Geoscience Research, 3(2): 100-108. 